\title{
Study of the Phenolic Composition of Shiraz Red Grape Cultivar (Vitis vinifera L.) Cultivated in North-eastern Thailand and its Antioxidant and Antimicrobial Activity
}

L. Butkhup ${ }^{1 *}$, S. Chowtivannakul' 2 R. Gaensakoo ${ }^{3}$, P. Prathepha ${ }^{3}$, S. Samappito ${ }^{3}$

(1) Laboratory Equipment Center, Division of Research Supporting and Extension Services, Mahasarakham University, Mahasarakham 44000, Thailand

(2) Division of Research Supporting and Extension Services, Mahasarakham University, Mahasarakham 44150, Thailand

(3) Department of Biotechnology, Faculty of Technology, Mahasarakham University, Mahasarakham 44000, Thailand

Submitted for publication: January 2010

Accepted for publication: May 2010

Key words: Shiraz, phenolic compounds, antioxidant activity, antimicrobial activity

\begin{abstract}
The seed, skin and whole grape extract of the red grape cultivar Shiraz, which is widely cultivated in Northeastern Thailand, were investigated. Total phenolic, total flavonoid and total monomeric anthocyanin content ranged from 48.04 to $116.73 \mathrm{~g} \mathrm{GAE} / 100 \mathrm{~g} \mathrm{db}$ (dry weight base), 74.82 to $258.69 \mathrm{mg} \mathrm{CE} / \mathrm{g} \mathrm{db}$, and 5.06 to 55.45 $\mathrm{mg} / 100 \mathrm{~g} \mathrm{db}$, respectively. Dimeric procyanidin $(119.56-484.08 \mathrm{mg} / 100 \mathrm{~g} \mathrm{db}),(+)$-catechin $(52.30-231.92 \mathrm{mg} / 100 \mathrm{~g}$ $\mathrm{db})$, (-)-epicatechin (27.92-174.10 $\mathrm{mg} / 100 \mathrm{~g} \mathrm{db})$, and gallic acid $(4.42-27.80 \mathrm{mg} / 100 \mathrm{~g} \mathrm{db})$ were found to be the main flavanols that were present in the seed. Rutin and trans-resveratrol were present in amounts of between 21.13 and 40.05 and 2.85 and $3.60 \mathrm{mg} / 100 \mathrm{~g}$ db respectively. All extracts showed remarkable DPPH radical-scavenging activity $\left(\mathrm{EC}_{50}\right)$, ranging from 0.47 to $2.10 \mu \mathrm{g} / \mathrm{mL}$. Methanolic extract from the seed and skin were also active against all Gram-positive bacteria, but these exerted less of an inhibiting effect on the growth of the tested Gram-negative bacteria. The activity of the methanolic extract of the seed was effective against $B$. cereus ATCC 11778, B. subtilis ATCC 6633 and $S$. faecalis TISTR 459.
\end{abstract}

\section{INTRODUCTION}

Grapes (Vitis vinifera L.) are considered the world's most prevalent fruit crop. Their large amounts of phenolic compounds have made them the focus of extensive studies (Broussaud et al., 1999; Caillet et al., 2006; Bozan et al., 2008). In grape berries, the phenolic compounds reside mainly in the skins and seeds (Rodriguez et al., 2006; Poudel et al., 2008). Flavonols are the most abundant phenolic compounds in grape skins, while grape seeds are rich in monomeric phenolic compounds, such as (+)-catechins, (-)-epicatechin and (-)-epicatechin-3-Ogallate, and dimeric, trimeric and tetrameric procyanidins. These compounds act as antimutagenic and antiviral agents (Kammerer et al., 2004; Rodriguez et al., 2006), and inhibit the oxidation of human low-density lipoproteins (LDL) in vitro (Teissedre et al., 1996). They undergo partial extraction during the winemaking process. Phenolics play an important role in the quality of grapes and wines. They can be divided into two groups: non-flavonoid (hydroxybenzoic and hydroxycinnamic acids and stilbenes) and flavonoid compounds (anthocyanins, flavan-3-ols and flavonols) (Rodriguez et al., 2006). Anthocyanins are a family of phenolics that are directly responsible for colour in grapes and young wines. Anthocyanins may react with flavanols to produce more stable pigments, either directly or by means of different aldehydes (e.g. acetaldehyde, propionaldehyde) (Pisarra et al., 2003). Flavan3-ols (monomeric catechins and proanthocyanidins) are another large family of phenolic compounds that are mainly responsible for the astringency, bitterness and structure of wines. They are also responsible for the browning reactions in grapes and wine
(Macheix et al., 1991) and undergo different reactions with anthocyanins that lead to the stabilisation of colour in red wines. Finally, phenolics, particularly certain phenolic acids, participate in the phenomenon of co-pigmentation. The last group of flavonoids are flavonols (quercetin, myricetin, kaempferol, isorhamnetin and their glycosides), which are potent antioxidants. Phenolic compounds in grapes and wine have attracted much interest due to their antioxidant properties (Kanner et al., 1994; Llobera \& Canellas, 2007) and their potentially beneficial effects on human health (Teissedre et al., 1996; Vitseva et al., 2005). Recognition of the health benefits of catechins and procyanidins has led to the use of grape seed extract as a dietary antioxidant supplement (Santos-Buelga \& Scalbert, 2000; Guendez et al., 2005; Bozan et al., 2008; Maier et al., 2009). The main phenolic antioxidants can also be used to preserve food because of their protective effects against microorganisms (Shoko et al., 1999; Jayaprakasha et al., 2003; Vattem et al., 2004). Phenolic antimicrobial compounds are found in grape seeds, skins and stem extracts (Jayaprakasha et al., 2003).

In Thailand, red grapes are grown in the northeast of the country. The district of Pak Chong in Nakhon Ratchasima province is the best suited area to produce red grapes in Thailand. Pak Chong supports a large viticultural area, and in recent years has grown to become one of the most important grape- and wine-producing areas in Thailand (Woraratphoka et al., 2007). Shiraz is a darkskinned variety of grape. It is grown in many countries and is used primarily to produce excellent red wines, which enjoy great popularity in the marketplace. According to several studies, Shiraz 
grape skins are rich in anthocyanins and flavonols (Downeya \& Rochfort 2008), while the proanthocyanidins are present mainly in the seeds (Cosme et al., 2009). Unfortunately, the literature lacks detailed information on the phenolic composition, antioxidant capacities (of DPPH free radicals) and antimicrobial activity of red grapes (cultivar Shiraz) grown in a warm climate like that of Thailand.

The objective of this study was to analyse phenolic composition using the spectrophotometrical determination of total phenolic content (TPC), total flavonoid content (TFC), total monomeric anthocyanin content (TAC), and individual phenolic compounds by RP-HPLC. The radical scavenging activities against stable 2,2-diphenyl-1-picrylhydrazyl (DPPH) and antimicrobial activity against 15 food spoilage and pathogenic microorganisms of grape seed extract (GSD), grape skin extract (GSK) and whole grape extract (WG) were evaluated.

\section{MATERIALS AND METHODS}

\section{Reagents and chemicals}

1,1-Diphenyl-2-picrylhydrazyl (DPPH) was obtained from Sigma Chemical Co. (St. Louis, MO, USA). Methanol, acetonitrile and phosphoric acids were of HPLC grade (Tedia Company, USA). Deionised water was prepared by a Milli-QWater purification system (Millipore, MA, USA). Gallic acid, (+)-catechin, $(-)$-epicatechin, rutin, procyanidin $\mathrm{B} 1$, caffeic acid, procyanidin $\mathrm{B} 2$, vanillic acid, myricetin, ellagic acid, trans-resveratrol, ferulic acid, luteolin, quercetin, naringenin and kaempferol standards were purchased from Sigma (Sigma Chemical Co., St Louis, MO, USA). All the other chemicals and solvents were reagent grade and purchased from Sigma and Fisher Scientific, Inc. (Pittsburgh, PA, USA). Standard stock solutions of phenolic compounds were prepared in methanol at a concentration of $500 \mathrm{mg} / \mathrm{L}$. All sample solutions were filtered through a $0.45 \mu \mathrm{m}$ membrane filter (Millipore MA, USA), and injected directly.

\section{Sample collection}

This study was carried out with Vitis vinifera $\mathrm{cv}$. Shiraz from the Pak Chong district of Nakhon Ratchasima province, North-eastern Thailand, during 2008. Roughly 1000 grapes were collected randomly on September 10, corresponding to eight weeks after véraison. Grapes were also selected randomly within the vine to ensure a homogeneous distribution between grapes that had been exposed to either more or less sunlight. Grapes were collected from each bunch and randomly sampled: one was taken from the top, one from the bottom, and one from the middle of the cluster. Special care was taken to obtain an even distribution of berries from the inside and outside of the bunch. The selected berries were finger pressed to remove the juice and pulp. The seeds and skin were separated, washed several times with distilled water and then frozen in liquid nitrogen, ground to a fine powder, and stored at $-20^{\circ} \mathrm{C}$ until they were analysed.

\section{Extraction and hydrolysis}

Ground samples ( $5 \mathrm{~g}$ ) were extracted and hydrolysed with $50 \mathrm{~mL}$ of $60 \%$ aqueous methanol containing $1.2 \mathrm{M} \mathrm{HCl}$. The mixture was refluxed at $85^{\circ} \mathrm{C}$ for $2 \mathrm{~h}$ to ensure complete extraction (Butkhup \& Samappito, 2008). The extracts were then filtered through Whatman No. 1 paper under vacuum, and the residue was repeatedly extracted with the same solvent until it was colourless and centri- fuged (10 min, $5000 \mathrm{~g}$ ). Methanol was evaporated from the supernatants on a rotary evaporator at $50 \mathrm{~mm} \mathrm{Hg}$ pressure and $50^{\circ} \mathrm{C}$. The extract was kept in the freezer at $-20^{\circ} \mathrm{C}$ for further study.

\section{Determination of plant extractable matter}

The yield of evaporated dried extracts based on a dry weight basis was calculated from Eq. (1), shown below:

Extractable matter $(\%)=\left(W_{1} \times 100\right) / W_{2}$

where $W_{1}$ was the weight of extract after the evaporation of methanol and $W_{2}$ was the dry weight of the fresh plant sample.

\section{Determination of total phenol content (TPC)}

The total phenol content of the GSD, GSK and WG was determined by the Folin-Ciocalteu method (Kahkonen et al., 1999). The sample of each extract solution $(200 \mu \mathrm{L})$ was transferred to a test tube and then mixed thoroughly with $1 \mathrm{~mL}$ of Folin-Ciocalteu reagent. After mixing for $3 \mathrm{~min}, 0.8 \mathrm{~mL}$ of $7.5 \%$ (w/v) sodium carbonate was added. The mixtures were agitated with a vortex mixer and then allowed to stand in the dark for a further 30 min, after which they were centrifuged at $3300 \mathrm{~g}$ for $5 \mathrm{~min}$. The absorbance of extracts and a prepared blank were measured at 765 nm using a spectrophotometer (UV-vis model 1601, Shimadzu, Kyoto, Japan). The measurements were compared to a standard curve of prepared gallic acid solution and expressed as grams of gallic acid equivalents (GAE) per 100 gram extract, which was determined from known concentrations of gallic acid standard prepared similarly.

\section{Total flavonoid content (TFC)}

Total flavonoids were measured using a colorimetric assay developed by Dewanto et al. (2002). An aliquot of diluted sample or standard solution of (+)-catechin was added to $75 \mu \mathrm{L}$ of $\mathrm{NaNO}_{2}$ solution (7\%) and mixed for $6 \mathrm{~min}$, before adding $0.15 \mathrm{~mL}^{\circ} \mathrm{AlCl}_{3}$ (10\%). After $5 \mathrm{~min}, 0.5 \mathrm{~mL}$ of $1 \mathrm{M} \mathrm{NaOH}$ solution was added. The final volume was adjusted to $2.5 \mathrm{~mL}$ and mixed thoroughly, and the absorbance of the mixture was determined at $510 \mathrm{~nm}$. Total flavonoids were expressed as $\mathrm{mg}(+)$-catechin equivalent $\mathrm{g}^{-1}$ dry weight basis ( $\mathrm{mg} \mathrm{CE} / \mathrm{g} \mathrm{db}$ ), through the calibration curve of (+)-catechin (range from $0-400 \mu \mathrm{g} / \mathrm{mL}$ ). All samples were analysed in three replications.

\section{Total monomeric anthocyanin content (TAC)}

Monomeric anthocyanins were measured using a spectrophotometric $\mathrm{pH}$ differential protocol (Lee et al., 2005), and calculated as cyanidin-3-glucoside equivalents for the samples. The extracts were mixed thoroughly with $0.025 \mathrm{M}$ potassium chloride $(\mathrm{pH}$ 1.0) in a known dilution. The absorbance of the mixture was measured at 515 and $700 \mathrm{~nm}$ using distilled water to zero the spectrophotometer. The extracts were then combined with 0.4 $\mathrm{M}$ sodium acetate buffer ( $\mathrm{pH} 4.5$ ), and the absorbances were measured at the same wavelengths. The absorbance of the diluted sample $(A)$ was as in Eq. (2)

$$
A=\left(A_{515}-A_{700}\right) \mathrm{pH} 1.0-\left(A_{515}-A_{700}\right) \mathrm{pH} 4.5
$$

The anthocyanin content was calculated as the total of monomeric anthocyanin pigment from Eq. (3), shown below:

$$
\text { Anthocyanin }(\mathrm{mg} / \mathrm{g})=\frac{(A \times \mathrm{MW} \times \mathrm{DF} \times 1000)}{(\varepsilon \times 1)}
$$

where $A$ is the absorbance of the diluted sample and DF is the dilution factor. MW and $\varepsilon$ in this formula correspond to the 
predominant anthocyanin in the sample. Since the sample composition was unknown, the pigment content was calculated as cyanidin-3-glucoside, where $\mathrm{MW}=449.2$ and $\varepsilon=26,900$.

\section{HPLC analysis}

The determination of phenolic compounds was carried out as has been described in detail elsewhere (Kerem et al., 2004; Butkhup \& Samappito, 2008), and $20 \mu \mathrm{L}$ of the clear samples were analysed by RP-HPLC with diode array detector (DAD). HPLC apparatus, consisting of a Shimadzu (Shimadzu Cooperation Analytical \& Measuring Instruments Division Kyoto, Japan) LC-20AD Series pumping system, an SIL-10AD Series Auto injector system and an SPD-M20A Series Diode array detector, was used to record online UV spectra of the phenolics in the samples. The data were collected and analysed with a Shimadzu computing system. The column used was an Apollo $\mathrm{C}_{18}$ (Alltech Associates, Deerfield, IL, USA) (ø $4.6 \mathrm{~mm} \times 250 \mathrm{~mm}, 5 \mu \mathrm{m})$ protected with guard column Inertsil ODS-3 (ø $4.0 \mathrm{~mm} \times 10 \mathrm{~mm}, 5 \mu \mathrm{m}$; GL Science Inc., Tokyo, Japan). The mobile phase for the phenolic determination was acetonitrile-deionised water $(2: 97.8, \mathrm{v} / \mathrm{v})$ containing $0.2 \%$ phosphoric acid (solvent A) and acetonitrile-deionised water (97.8:2, v/v) containing 0.2\% phosphoric acid (solvent B) at a flow rate of $0.6 \mathrm{~mL} \cdot \mathrm{min}^{-1}$ and a column temperature of $40^{\circ} \mathrm{C}$. The linear gradient started with $20 \%$ solvent B, $50 \%$ solvent B at 30 min, $60 \%$ solvent $\mathrm{B}$ at $35 \mathrm{~min}$, and $20 \%$ solvent $\mathrm{B}$ at $40 \mathrm{~min}$ at isocratic elution until $55 \mathrm{~min}$. Phenolic compounds were recorded from 190 to $400 \mathrm{~nm}$, with detection at $254 \mathrm{~nm}$, and identified according to their retention times and UV spectra by comparing them with those of standards. New standards were prepared and analysed daily. Quantification was carried out by using calibration curves that were obtained using the commercial standards of the concentrations normally present in oenological samples (approximately 1-400 mg/L), obtaining regression coefficients $\left(\mathrm{r}^{2}\right)$ above 0.995 in all cases.

\section{Scavenging activity on 2,2-diphenyl-2-picrylhydrazyl radical} (AA)

A $0.1 \mathrm{~mL}$ aliquot of the methanol extract prepared above was mixed with $3.9 \mathrm{~mL}$ of an $80 \%$ ethanolic $0.6 \mathrm{mM}$ DPPH solution. The tubes were vortexed for $15 \mathrm{~s}$ and allowed to stand for $180 \mathrm{~min}$, as described by Cai et al. (2003), after which the absorbance of the mixture was measured at $517 \mathrm{~nm}$ using the Hewlett Packard UVVis spectrophotometer (UV-Vis model 1601, Shimadzu, Kyoto, Japan). Most tested compounds should react completely within 180 min under these conditions, and the reaction time for vitamin $\mathrm{C}$ is less than $1 \mathrm{~min}$ due to its fast oxidation. Ethanol $(80 \%)$ was used as a blank solution, and DPPH solution without test samples (3.9 $\mathrm{mL}$ of DPPH $+0.1 \mathrm{~mL}$ of $80 \%$ ethanol) served as the control. All the tests were performed in triplicate. The antioxidant activity of the test samples was expressed, firstly as the median effective concentration for radical-scavenging activity $\left(\mathrm{EC}_{50}\right)$ : total phenolics $(\mathrm{mg})$ of antioxidant (test sample) required for a $50 \%$ decrease in absorbance of DPPH radicals. This characteristic parameter is called efficient concentration $\left(\mathrm{EC}_{50}\right)$ or oxidation index, and the lower it becomes, the higher is the antioxidant activity of the examined product. The antiradical activity $\left(\mathrm{A}_{\mathrm{AR}}\right)$ was determined as the inverse value of the efficient concentration $\mathrm{EC}_{50}$, representing a comparable term for the effectiveness of antioxidant and radical-scavenging capacity: $\mathrm{A}_{\mathrm{AR}}=1 / \mathrm{EC}_{50}$. The larger the $\mathrm{A}_{\mathrm{AR}}$, the more efficient was the antioxidant. Secondly, the percentage inhibition was calculated from Eq. (4) below:

$\%$ inhibition $=\frac{\left(\mathrm{A}_{\text {control }}-\mathrm{A}_{\text {test }}\right) \times 100}{\mathrm{~A}_{\text {control }}}$

A plot of absorbance of DPPH vs. concentration of antioxidant was made to establish the standard curves (dose-response curves) and to calculate $\mathrm{EC}_{50}$. $\mathrm{A}_{\text {control }}$ is the absorbance of the control (DPPH solution without the test sample), and $\mathrm{A}_{\text {test }}$ is the absorbance of the test sample (DPPH solution plus $0.1 \mathrm{ml}$ of $5 \mu \mathrm{M}$ of test compound). Ascorbic acid served as a standard, and the results of the assay were expressed relative to ascorbic acid equivalent.

\section{Preparation of test microorganisms}

The microbial strains were obtained from the American Type Culture Collection (ATCC; Rockville, MD, USA). They included the Gram-positive bacteria: Bacillus cereus ATCC 11778, Bacillus subtilis ATCC 6633, Staphylococcus aureus ATCC 13150 and Streptococcus thermophilus ATCC 19258; the Gram-negative bacteria: Escherichia coli ATCC 29214, Salmonella typhi ATCC 43579, Vibrio chlolerea ATCC 14033 and Shigella dysenteriae ATCC 13313; and the yeasts: Candida tropicalis ATCC 9968, Saccharomyces cerevisiae ATCC 18824 and Kluyveromyces marxianus ATCC 8554. The Gram-positive bacteria Streptococcus faecalis TISTR 459 and Streptococcus cremoris TISTR 058; the Gram-negative bacterium Proteus vulgaris TISTR 100; and the yeast Candida krusei TISTR 5256 were obtained from the culture collection at Thailand Institute of Scientific and Technological Research (TISTR, Thailand), and were employed for the determination of antimicrobial activity. This investigation was carried out at the Microbiology Laboratory, Department of Biotechnology, Technology Faculty, Mahasarakham University, Thailand.

The bacterial and yeast stock cultures were stored at $-22^{\circ} \mathrm{C}$ in $40 \%(\mathrm{v} / \mathrm{v})$ glycerol-either nutrient or yeast malt broth. The working bacterial culture and yeast culture were grown on nutrient agar at $37^{\circ} \mathrm{C}$ for $24 \mathrm{~h}$ and in yeast malt agar at $30^{\circ} \mathrm{C}$ for $48 \mathrm{~h}$, respectively. To obtain cells in the stationary growth phase, the bacterial culture and yeast culture were subcultured twice, at $37^{\circ} \mathrm{C}$ for $24 \mathrm{~h}$ on nutrient broth and at $30^{\circ} \mathrm{C}$ for $48 \mathrm{~h}$ in yeast malt broth, respectively. Cells were harvested by centrifugation at $6000 \times \mathrm{g}$ for $2 \mathrm{~min}$ and washed once with a $5 \mathrm{mM} \mathrm{NaCl}$ solution. The supernatant was discarded and the cells were washed again. Bacterial cells and yeast cells were re-harvested and suspended in fresh nutrient broth and yeast malt broth respectively. The concentration of cultures was to $10^{6}$ colony-forming units $(1 \times$ $10^{6} \mathrm{CFU} / \mathrm{mL}$ ).

\section{Antimicrobial assay}

The antimicrobial activity of GSD, GSK and WG were determined separately using the disc diffusion method as described by Mackeen et al. (1997). Two hundred microlitres of prepared culture was spread on surfaces of Mueller Hinton agar (MHA). Ten microlitres $(1 \mathrm{mg} / \mathrm{mL})$ of each extract was applied to a sterile filter paper disc (Whatman No. 1; $6 \mathrm{~mm}$ in diameter) and allowed to dry for $15 \mathrm{~min}$. The discs were then placed on the surface of the inoculated medium. The plates were inverted and incubated for $24 \mathrm{~h}$ at $37^{\circ} \mathrm{C}$. Each test was carried out in triplicate, with controls. Antibiotic susceptibility discs including ampicillin $(10 \mu \mathrm{g} / \mathrm{disc})$, 
ciprofloxacin $(10 \mu \mathrm{g} / \mathrm{disc})$ and ketoconazole $(10 \mu \mathrm{g} / \mathrm{disc})$ were used as a positive control. The solvent of each extract was used as a negative control. The results were recorded by measuring the zones of growth inhibition surrounding the discs. Clear inhibition zones around the discs indicate the presence of antimicrobial activity.

\section{Minimum inhibitory concentration (MIC)}

The minimum inhibitory concentrations (MIC) were determined for GSD, GSK and WG showing antibacterial activity in the disc diffusion assay. Concentrated extracts of GSD, GSK and WG were added at two-fold serial dilution (0 to $2640 \mu \mathrm{g} / \mathrm{mL}$ ) to sterilize MHA (Mackeen et al., 1997). Ten microlitres of an overnight culture of each microbial strain, containing approximately $10^{6}$ $\mathrm{CFU}$, was applied on the agar surfaces. MIC values were taken as the lowest concentration of extract that completely inhibited microbial growth after $24 \mathrm{~h}$ of incubation at $37^{\circ} \mathrm{C}$.

\section{Statistical analysis}

All the data reported below were evaluated in triplicate in each of the samples. The statistical analysis of the data was carried out by analysis of the variance (ANOVA) and the Scheffe test to show measurements that could be considered statistically different. A significance level of $\alpha=0.05$ was used. $\mathrm{EC}_{50}$ values for all the above experiments were determined by linear regression.

\section{RESULTS}

\section{Total phenols, total flavonoids, total monomeric anthocyanins and composition of individual phenolics}

As can be seen in Table 1, the extractable matter was $18.30 \%$, $13.62 \%$ and $6.10 \%$ for the seeds, skins and whole grape respectively. The whole grape contained a significantly high moisture level $(77.62 \%)$, followed by the grape skins $(58.76 \%)$ and the grape seeds $(45.49 \%)$.

The results show that the total phenolic content (TPC) was highest in the GSD (116.73 $\mathrm{g} \mathrm{GAE} / 100 \mathrm{~g} \mathrm{db})$, followed by the GSK (75.20 g GAE/100 g db) and the WG (48.04 g GAE/100 g $\mathrm{db})$. The differences in the TPC of the tissue analysed were also significant $(p<0.05)$ (Table 1$)$. The total flavonoid content of the tissue studied was highest in the GSD (258.69 $\mathrm{mg} \mathrm{CE} / \mathrm{g} \mathrm{db}$ ), followed by the GSK (147.12 mg CE/g db) and the WG (74.82 mg $\mathrm{CE} / \mathrm{g} \mathrm{db}$ ). Total monomeric anthocyanins (TAC), as assessed by spectrophotometry, showed clear significant differences $(p<0.05)$ (Table 1). As expected, anthocyanins were high in the GSK and low in the WG and GSD, as anthocyanins are only present in the skin in Vitis vinifera species. The GSK had a higher level of TAC $(55.45 \mathrm{mg} / 100 \mathrm{~g} \mathrm{db})$ than the WG $(36.15 \mathrm{mg} / 100 \mathrm{~g} \mathrm{db})$ and GSD $(5.06 \mathrm{mg} / 100 \mathrm{~g} \mathrm{db})$ respectively.

RP-HPLC analyses were carried out to provide a quantitative measurement of the phenolic profiles (Table 1), expressed in $\mathrm{mg} / 100 \mathrm{~g}$ on a dry weight basis. The differences in the tissue analysed, i.e. GSD, GSK and WG, was reflected in the detailed individual phenolic profiles. Statistically significant differences $(p<0.05)$ were found between the tissue analysed for each compound assayed. GSD contained significantly more of the sum of individual flavonoids than GSK $(205.44 \mathrm{mg} / 100 \mathrm{~g} \mathrm{db})$ and WG $(109.11 \mathrm{mg} / 100 \mathrm{~g} \mathrm{db})$ respectively. The individual flavonoid content of the red grape cultivar Shiraz was divided into three groups: high (>10 mg/100 g db), moderate $(1.00-10.00 \mathrm{mg} / 100 \mathrm{~g}$ $\mathrm{db})$ and low (<1.00 mg/100 g db). (+)-Catechin, (-)-epicatechin and rutin were in the high group, with concentrations ranging from 21.13 to $231.92 \mathrm{mg} / 100 \mathrm{~g} \mathrm{db}$ of GSD, and were the predominant compounds in all samples. Trans-resveratrol, naringenin and kaempferol were in the moderate concentration group, whereas low concentrations of quercetin and luteolin were also obtained in the tissue analysed. Among the tissue analysed, GSD showed the highest content of (+)-catechin $(231.92 \mathrm{mg} / 100 \mathrm{~g} \mathrm{db})$, (-)-epicatechin $(174.10 \mathrm{mg} / 100 \mathrm{~g} \mathrm{db})$ and the sum of individual flavonoids $(431.26 \mathrm{mg} / 100 \mathrm{~g} \mathrm{db})$, whereas the highest content of rutin $(40.05 \mathrm{mg} / 100 \mathrm{~g} \mathrm{db})$, myricetin $(2.02 \mathrm{mg} / 100 \mathrm{~g} \mathrm{db})$, naringenin $(2.96 \mathrm{mg} / 100 \mathrm{~g} \mathrm{db})$ and kaempferol $(1.27 \mathrm{mg} / 100 \mathrm{~g}$ $\mathrm{db}$ ) were present in the GSK (these compounds are believed to be localised in the grape vacuoles of exocarp (peel) cells). However, no marked differences in trans-resveratrol, luteolin and quercetin content were found in the analysed tissues.

Four compounds were quantified in the group of phenolic acids. The results showed a significant $(p<0.05)$ sum of individual phenolic acids in the tissue analysed. In general, gallic acid was the major phenolic acid in the GSD and GSK, with an average level of $27.80 \mathrm{mg} / 100 \mathrm{~g} \mathrm{db}$ (GSD) and $16.45 \mathrm{mg} / 100 \mathrm{~g} \mathrm{db}$ (GSK). Minor phenolic acids found in the grape were caffeic acid and ellagic acid. Ferulic acid was present mainly in the GSK (4.20 $\mathrm{mg} / 100 \mathrm{~g} \mathrm{db})$ and WG $(4.17 \mathrm{mg} / 100 \mathrm{~g} \mathrm{db})$. This is to be expected, as there are only trace amounts of phenolics in the pulp of grape berries.

\section{Antioxidant activity (AA)}

The antioxidant activity of the extracts was evaluated by the decrease in the peak area of the DPPH radical at $517 \mathrm{~nm}$. The amount of DPPH radical significantly $(p<0.05)$ decreased in the presence of GSD, GSK and WG. Values for the percentage of decolourisation of DPPH radicals are listed in Table 2. The antioxidant ascorbic acid was used as a reference. The DPPH radical-scavenging capacity of GSD, GSK and WG was dose dependent in the concentration range used in the study $(0.01-2.00$ $\mathrm{mg} / \mathrm{mL}$ ), as presented in Table 2. A sharp increase in radical scavenging activity with an increase in the concentration of extract was observed at $0.10 \mathrm{mg} / \mathrm{mL}$ concentration. At this concentration, the GSD showed significantly higher activity $(32.86 \%)$ than the ascorbic acid. The tissue extracts from the GSD, GSK and WG were analysed and showed significantly different values for DPPH radical-scavenging activity. The values were $86.74 \%$ (GSD), $80.10 \%$ (GSK) and $70.13 \%$ (WG) at a concentration of $2.00 \mathrm{mg} / \mathrm{mL}$. On the other hand, the higher activity of GSD, GSK and WG can be attributed to a more elevated concentration of the TPC and antioxidants.

The $\mathrm{EC}_{50}(\mu \mathrm{g} / \mathrm{mL})$ values obtained for the samples submitted to the DPPH assay ranged from 0.47 to $2.10 \mu \mathrm{g} / \mathrm{mL}$. The lowest $\mathrm{EC}_{50}$ values found were for GSD $(0.47 \mu \mathrm{g} / \mathrm{mL})$, which was also the richest in phenolics. GSK $(1.06 \mu \mathrm{g} / \mathrm{mL})$ and WG $(2.10 \mu \mathrm{g} /$ $\mathrm{mL}$ ) exhibited moderate activity. The larger the $\mathrm{A}_{\mathrm{AR}}$, the more efficient the antioxidant, as can be found in the $\operatorname{GSD}\left(\mathrm{A}_{\mathrm{AR}}=2.13\right)$ more so than in the GSK $\left(\mathrm{A}_{\mathrm{AR}}=0.94\right)$ and $\mathrm{WG}\left(\mathrm{A}_{\mathrm{AR}}=0.47\right)$.

\section{Antimicrobial activity}

The results of the antimicrobial activity of GSD, GSK and WG against 15 microbial species are summarised in Table 3 (inhibition zones in the disc diffusion method and MIC values). The methanolic 
TABLE 1

Moisture content, extractable matter, total phenolic content (TPC), total flavonoid content (TFC), total monomeric anthocyanin content (TAC) and individual phenolic content of the grape seed extract (GSD), grape skin extract (GSK) and whole grape extract (WG).

\begin{tabular}{|c|c|c|c|}
\hline \multirow{2}{*}{ Parameter } & \multicolumn{3}{|c|}{ Tissue analysed } \\
\hline & GSD & GSK & WG \\
\hline Moisture content $(\%)$ & $45.49 \mathrm{c} \pm 2.42$ & $58.76 \mathrm{~b} \pm 1.31$ & $77.62 \mathrm{a} \pm 2.50$ \\
\hline Extractable matter (\%) & $18.30 \mathrm{a} \pm 1.10$ & $13.62 \mathrm{~b} \pm 1.03$ & $6.10 \mathrm{c} \pm 0.53$ \\
\hline TPC (g GAE/100 g db) ${ }^{\mathrm{a}}$ & $116.73 \mathrm{a} \pm 1.14$ & $75.20 \mathrm{~b} \pm 2.10$ & $48.04 \mathrm{c} \pm 1.30$ \\
\hline TFC (mg CE/g db) ${ }^{b}$ & $258.69 \mathrm{a} \pm 2.10$ & $147.12 b \pm 1.14$ & $74.82 \mathrm{c} \pm 1.10$ \\
\hline $\mathrm{TAC}(\mathrm{mg} / 100 \mathrm{~g} \mathrm{db})^{\mathrm{c}}$ & $5.06 \mathrm{c} \pm 0.32$ & $55.45 \mathrm{a} \pm 1.40$ & $36.15 \mathrm{~b} \pm 1.22$ \\
\hline \multicolumn{4}{|l|}{ Flavonoids $^{\mathrm{d}}$} \\
\hline$(+)$-Catechin & $231.92 \mathrm{a} \pm 1.12$ & $103.70 b \pm 1.60$ & $52.30 \mathrm{c} \pm 1.13$ \\
\hline$(-)$-Epicatechin & $174.10 \mathrm{a} \pm 1.18$ & $51.20 \mathrm{~b} \pm 1.02$ & $27.92 \mathrm{c} \pm 1.40$ \\
\hline Rutin & $21.13 \mathrm{c} \pm 0.43$ & $40.05 \mathrm{a} \pm 0.61$ & $23.70 \mathrm{~b} \pm 0.87$ \\
\hline Myricetin & $0.54 \mathrm{~b} \pm 0.02$ & $2.02 \mathrm{a} \pm 0.10$ & $0.40 \mathrm{~b} \pm 0.02$ \\
\hline trans-Resveratrol ns & $2.85 \pm 0.14$ & $3.60 \pm 0.10$ & $3.02 \pm 0.10$ \\
\hline Luteolin ${ }^{\text {ns }}$ & $0.22 \pm 0.01$ & $0.14 \pm 0.01$ & nd \\
\hline Quercetin $^{\text {ns }}$ & nd & $0.50 \pm 0.02$ & $0.44 \pm 0.03$ \\
\hline Naringenin & $0.37 \mathrm{c} \pm 0.01$ & $2.96 \mathrm{a} \pm 0.14$ & $1.17 \mathrm{~b} \pm 0.15$ \\
\hline Kaempferol & $0.13 \mathrm{~b} \pm 0.02$ & $1.27 \mathrm{a} \pm 0.03$ & $0.16 \mathrm{~b} \pm 0.02$ \\
\hline Sum of individual flavonoids & $431.26 \mathrm{a} \pm 1.59$ & $205.44 b \pm 1.21$ & $109.11 \mathrm{c} \pm 1.62$ \\
\hline \multicolumn{4}{|l|}{ Procyanidins ${ }^{\mathrm{d}}$} \\
\hline Procyanidin B1 & $240.13 \mathrm{a} \pm 2.80$ & $194.24 b \pm 4.52$ & $119.56 \mathrm{c} \pm 2.15$ \\
\hline Procyanidin B2 & $484.08 \mathrm{a} \pm 1.62$ & $145.29 \mathrm{~b} \pm 2.40$ & $123.60 \mathrm{c} \pm 2.09$ \\
\hline Sum of individual procyanidins & $724.21 \mathrm{a} \pm 1.75$ & $339.53 b \pm 3.06$ & $243.16 \mathrm{c} \pm 2.11$ \\
\hline \multicolumn{4}{|l|}{ Phenolic acids ${ }^{\mathrm{d}}$} \\
\hline Gallic acid & $27.80 \mathrm{a} \pm 1.24$ & $16.45 \mathrm{~b} \pm 1.29$ & $4.42 \mathrm{c} \pm 0.03$ \\
\hline Caffeic acid & $0.48 \mathrm{~b} \pm 0.01$ & $1.58 \mathrm{a} \pm 0.13$ & $0.62 b \pm 0.02$ \\
\hline Ellagic acid ${ }^{\mathrm{ns}}$ & $0.23 \pm 0.06$ & $0.18 \pm 0.04$ & $0.13 \pm 0.02$ \\
\hline Ferulic acid & $0.81 \mathrm{~b} \pm 0.03$ & $4.20 \mathrm{a} \pm 0.13$ & $4.17 \mathrm{a} \pm 0.30$ \\
\hline Sum of individual phenolic acids & $29.32 \mathrm{a} \pm 0.86$ & $22.41 \mathrm{~b} \pm 0.52$ & $9.34 \mathrm{c} \pm 2.09$ \\
\hline
\end{tabular}

Values are the means \pm standard deviation $(n=3)$. nd, not detected. ns, not significant.

Means in the same row bearing different letters are significantly different $(p<0.05)$ as analysed by the Scheffe test.

a Total phenolic content ( $\mathrm{g}$ GAE/100 g db) by Folin-Ciocaltaeu, expressed as gallic acid equivalent (GAE).

b Total flavonoid content (mg CE/g db) by colorimetric assay, expressed as (+)-catechin equivalent (CE).

c Total monomeric anthocyanins $(\mathrm{mg} / 100 \mathrm{~g} \mathrm{db})$, expressed as cyanidin-3-glucoside equivalent.

${ }^{\mathrm{d}}$ Quantification of individual phenolic content (mg/100 $\mathrm{g} \mathrm{db}$ ) by RP-HPLC-DAD.

extracts of GSD, GSK and WG were evaluated using 11 bacterial strains and four yeast strains for their potential to inhibit the growth of food-borne pathogens and pathogenic microorganisms by the disc diffusion method. Methanol (control) had no inhibitory effects on the 15 microorganism tested. The investigated extract was active against all Gram-positive bacteria, but exerted less of an inhibitory effect on the growth of the tested Gram-negative bacteria. However, the tested bacteria showed more sensitivity to the investigated extracts than to the yeast strains. Both GSD and GSK exhibited the largest zones of inhibition for Grampositive bacteria: Bacillus cereus ATCC 11778, Bacillus subtilis ATCC 6633, Staphylococcus aureus ATCC 13150, Streptococcus faecalis TISTR 459 and Streptococcus cremoris TISTR 058 (10$15 \mathrm{~mm}$ ), whereas the smallest zone of activity (inhibition zone of 4-9 mm) was against Gram-negative bacteria: Escherichia coli ATCC 29214, Shigella dysenteriae ATCC 13313, Salmonella typhi ATCC 43579 and Vibrio chlolerea ATCC 14033. However, both GSD and GSK exhibited higher activities than WG for the 
inhibition of Gram-positive and Gram-negative bacteria. WG showed antibacterial activity against Gram-positive bacteria only. Only the GSD showed any activity against $V$. chlolerea ATCC 14033 (Gram-negative) and Kluyveromyces marxianus ATCC 8554 (yeast).

The disc diffusion method provides an opportunity to determine an approximate MIC, indicating the degree of potential antimicrobial activity compared with that of the positive control, ampicillin, ciprofloxacin and ketoconazole. The results obtained from the grape extracts were very promising, especially the activity of the methanolic extract of the seeds (GSD), which was effective against B. cereus ATCC 11778, B. subtilis ATCC 6633 and $S$. faecalis TISTR $459(\mathrm{MIC}=16 \mu \mathrm{g} / \mathrm{mL})$. The highest MIC value of $512 \mu \mathrm{g} / \mathrm{mL}$ for GSK was estimated for $E$. coli ATCC 29214. The activity of the GSD and GSK against both Grampositive and Gram-negative bacteria may be indicative of the presence of broad-spectrum antibiotic compounds, which are distributed mainly in the seeds and skins of grapes.

\section{DISCUSSION}

The Folin-Ciocalteu method is a rapid and widely-used assay to determine total phenolic content (TPC) (Kahkonen et al., 1999). This method is based on the reducing power of phenolic hydroxyl groups, but it is known that different phenolic compounds have different responses to the Folin-Ciocalteu reagent. The TPC in each grape extract was spectrophotometrically determined according to the Folin-Ciocalteu procedure by reading the absorbances at $760 \mathrm{~nm}$, and the results were expressed as grams of gallic acid equivalents (GAE) per $100 \mathrm{~g}$ of extract. TPC was evaluated for the tested seed, skin and whole grape extracts, because they contribute to the overall antioxidant activity. The TPC of both the GSD and GSK was higher than that of the WG, with average values of 2.43 and 1.57 times higher respectively. It has been noted that the TPC of the GSD was higher than that in commercial grape seed extract (80.70 g GAE/100 g seed) reported by Caillet et al. (2006) and in seeds of red grape varieties cultivated in Turkey (7.90-15.46 g GAE/100 g seed) (Bozan et al., 2008). On the other hand, the data for the GSK from the present study were higher than those reported previously for Cabernet Sauvignon, Merlot and Shiraz red grape skins (Arnous \& Meyer, 2008), but slightly lower than those reported in commercial grape skin extracts $(79.20 \mathrm{~g}$ GAE/100 g) (Caillet et al., 2006). However, in the present study, sugars, proteins and pigments were not removed prior to testing, which may have added to the high values seen when detecting the total phenolic content. In addition, the discrepancies may be due to differences in cultivar, cultivation site, climate, viticultural technique and harvesting time.

Total flavonoid contents (TFC) of the GSD, GSK and WG were determined as described by Dewanto et al. (2000). All values were expressed as $\mathrm{mg}(+)$-catechin equivalent per gram dry weight basis ( $\mathrm{mg} \mathrm{CE} / \mathrm{g} \mathrm{db}$ ). The TFC of the tissue studied was highest in the GSD (258.69 $\mathrm{mg} \mathrm{CE} / \mathrm{g} \mathrm{db}$ ). The values of the total flavonoid content in the GSD were higher than those reported for the varieties Merlot (122.70 $\mathrm{mg} \mathrm{CE} / \mathrm{g} \mathrm{db}$ ) and Cabernet (125.00 $\mathrm{mg} \mathrm{CE} / \mathrm{g} \mathrm{db}$ ) (Bozan et al., 2008) and for other red grape seeds (102.58 mg CE/g db) (Makris et al., 2007). The difference is presumably due to the extraction method, which might have caused partial degradation of the flavonoids, and may be due to the different variety and source of grapes. Likewise, our TFC values for the GSK were higher than those reported previously for red grape peel (35.87 mg CE/g db) (Makris et al., 2007) and five wild grapes and two hybrids native to Japan $(0.3-3.4 \mathrm{mg}$ QE/g) (Poudel et al., 2008). We ascribe the difference mainly to the type of extraction method employed. However, quantitative differences might also be a factor of cultivar, cultivation site, climate and viticultural technique.

Anthocyanins, belonging to the flavonoid family of phytochemicals, have received attention as agents that may have potential in preventing chronic diseases such as cardiovascular diseases and certain cancers. Singletary et al. (2007) reported that the grape anthocyanins have breast cancer chemopreventive potential due, in part, to their capacity to block carcinogenDNA adduct formation, modulate the activities of carcinogenmetabolising enzymes, and suppress ROS in noncancerous human

\section{TABLE 2}

Antioxidant activity (\%) of the GSD, GSK and WG measured by the scavenging of DPPH radicals

\begin{tabular}{|c|c|c|c|c|}
\hline \multirow{2}{*}{ Parameter } & \multicolumn{3}{|c|}{ Tissue analysed } & \multirow{2}{*}{ Ascorbic acid } \\
\hline & GSD & GSK & WG & \\
\hline \multicolumn{5}{|c|}{ Antioxidant activity (\%) } \\
\hline $0.01 \mathrm{mg} / \mathrm{mL}$ & $12.09 \mathrm{~b} \pm 1.21$ & $11.64 b \pm 0.83$ & $10.84 \mathrm{~b} \pm 1.13$ & $15.46 \mathrm{a} \pm 0.24$ \\
\hline $0.10 \mathrm{mg} / \mathrm{mL}$ & $32.86 \mathrm{~b} \pm 0.57$ & $18.35 \mathrm{c} \pm 1.15$ & $17.13 \mathrm{c} \pm 1.04$ & $22.89 \mathrm{~b} \pm 1.40$ \\
\hline $0.50 \mathrm{mg} / \mathrm{mL}$ & $67.98 \mathrm{~b} \pm 1.01$ & $52.30 \mathrm{c} \pm 1.00$ & $41.25 \mathrm{~d} \pm 1.20$ & $71.46 \mathrm{a} \pm 2.10$ \\
\hline $1.00 \mathrm{mg} / \mathrm{mL}$ & $77.52 \mathrm{~b} \pm 1.10$ & $74.15 \mathrm{c} \pm 1.20$ & $68.04 \mathrm{~d} \pm 1.16$ & $85.52 \mathrm{a} \pm 3.12$ \\
\hline $1.50 \mathrm{mg} / \mathrm{mL}$ & $82.04 \mathrm{~b} \pm 3.12$ & $79.42 \mathrm{c} \pm 2.11$ & $71.45 \mathrm{~d} \pm 1.30$ & $91.03 \mathrm{a} \pm 2.46$ \\
\hline $2.00 \mathrm{mg} / \mathrm{mL}$ & $86.74 \mathrm{~b} \pm 1.02$ & $80.10 \mathrm{c} \pm 1.04$ & $75.02 \mathrm{~d} \pm 1.17$ & $96.38 \mathrm{a} \pm 3.06$ \\
\hline $\mathrm{EC}_{50}(\mu \mathrm{g} / \mathrm{mL})$ & $0.47 \mathrm{~d} \pm 0.01$ & $1.06 \mathrm{~b} \pm 0.02$ & $2.10 \mathrm{a} \pm 0.10$ & $0.15 \mathrm{c} \pm 0.03$ \\
\hline $\mathrm{A}_{\mathrm{AR}}\left(1 / \mathrm{EC}_{50}\right)$ & $2.13 \mathrm{~b} \pm 0.01$ & $0.94 \mathrm{c} \pm 0.01$ & $0.47 \mathrm{~d} \pm 0.05$ & $6.67 \mathrm{a} \pm 0.02$ \\
\hline
\end{tabular}

Values are the means \pm standard deviation $(n=3)$.

Means in the same row bearing different letters are significantly different $(p<0.05)$ as analysed by the Scheffe test. 
TABLE 3

Antimicrobial activity of the methanolic GSD, GSK and WG.

\begin{tabular}{|c|c|c|c|c|c|c|c|c|c|}
\hline \multirow{2}{*}{ Microorganism } & \multicolumn{6}{|c|}{ Inhibition zones (mm) against } & \multicolumn{3}{|c|}{$\mathrm{MIC}(\mu \mathrm{g} / \mathrm{mL})$} \\
\hline & GSD & GSK & WG & Amp & Cip & Ket & GSD & GSK & WG \\
\hline \multicolumn{10}{|l|}{ Gram-positive } \\
\hline $\begin{array}{l}\text { Bacillus cereus } \\
\text { ATCC } 11778\end{array}$ & $15 \pm 0.08$ & $12 \pm 0.10$ & $8 \pm 0.20$ & $16 \pm 0.36$ & $20 \pm 0.18$ & NT & 16 & 32 & 128 \\
\hline $\begin{array}{l}\text { Bacillus subtilis } \\
\text { ATCC } 6633\end{array}$ & $14 \pm 0.24$ & $10 \pm 0.41$ & $6 \pm 0.41$ & $26 \pm 0.58$ & $18 \pm 0.50$ & NT & 16 & 64 & 256 \\
\hline $\begin{array}{l}\text { Staphylococcus aureus } \\
\text { ATCC } 13150\end{array}$ & $12 \pm 0.10$ & $11 \pm 0.23$ & $10 \pm 0.34$ & $25 \pm 0.49$ & $20 \pm 0.54$ & NT & 32 & 64 & 64 \\
\hline $\begin{array}{l}\text { Streptococcus } \\
\text { thermophilus ATCC } 19258\end{array}$ & - & - & - & $12 \pm 0.37$ & $30 \pm 0.66$ & NT & NT & NT & NT \\
\hline $\begin{array}{l}\text { Streptococcus faecalis } \\
\text { TISTR } 459\end{array}$ & $14 \pm 0.14$ & $11 \pm 0.07$ & $10 \pm 0.12$ & $16 \pm 0.44$ & $20 \pm 0.52$ & NT & 16 & 64 & 64 \\
\hline $\begin{array}{l}\text { Streptococcus cremoris } \\
\text { TISTR } 058\end{array}$ & $13 \pm 0.20$ & $10 \pm 0.43$ & $9 \pm 0.36$ & $14 \pm 0.50$ & $23 \pm 0.14$ & NT & 32 & 64 & 128 \\
\hline \multicolumn{10}{|l|}{ Gram-negative } \\
\hline $\begin{array}{l}\text { Escherichia coli } \\
\text { ATCC } 29214\end{array}$ & $7 \pm 0.12$ & $4 \pm 0.06$ & - & $11 \pm 0.37$ & $30 \pm 0.56$ & NT & 256 & 512 & NT \\
\hline $\begin{array}{l}\text { Shigella dysenteriae } \\
\text { ATCC } 13313\end{array}$ & $8 \pm 0.24$ & $6 \pm 0.24$ & - & $15 \pm 0.54$ & $25 \pm 0.49$ & NT & 128 & 256 & NT \\
\hline $\begin{array}{l}\text { Salmonella typhi } \\
\text { ATCC } 43579\end{array}$ & $9 \pm 0.14$ & $6 \pm 0.12$ & - & - & $21 \pm 0.36$ & NT & 128 & 256 & NT \\
\hline $\begin{array}{l}\text { Proteus vulgaris } \\
\text { TISTR } 100\end{array}$ & - & - & - & $12 \pm 0.37$ & $25 \pm 0.24$ & NT & NT & NT & NT \\
\hline $\begin{array}{l}\text { Vibrio chlolerea } \\
\text { ATCC } 14033\end{array}$ & $6 \pm 0.52$ & - & - & $14 \pm 0.17$ & $22 \pm 0.19$ & NT & 256 & NT & NT \\
\hline \multicolumn{10}{|l|}{ Yeasts } \\
\hline $\begin{array}{l}\text { Candida krusei } \\
\text { TISTR } 5256\end{array}$ & - & - & - & NT & NT & $25 \pm 0.44$ & NT & NT & NT \\
\hline $\begin{array}{l}\text { Candida tropicalis } \\
\text { ATCC } 9968\end{array}$ & - & - & - & NT & NT & $8 \pm 0.52$ & NT & NT & NT \\
\hline $\begin{array}{l}\text { Kluyveromyces marxianus } \\
\text { ATCC } 8554\end{array}$ & $6 \pm 0.03$ & - & - & NT & NT & $18 \pm 0.36$ & 256 & NT & NT \\
\hline $\begin{array}{l}\text { Saccharomyces cerevisiae } \\
\text { ATCC } 18824\end{array}$ & - & - & - & NT & NT & $20 \pm 0.21$ & NT & NT & NT \\
\hline
\end{tabular}

Values are the means \pm standard deviation $(n=3)$. $(-)$ no inhibition at the concentration tested. NT, not tested. Positive control: Amp, Ampicillin $(10 \mu \mathrm{g} /$ disc); Cip, Ciprofloxacin $(10 \mu \mathrm{g} / \mathrm{disc})$; Ket, Ketoconazole $(10 \mu \mathrm{g} / \mathrm{disc})$.

breast cells. Anthocyanins are an important quality parameter of grape berries, due to their importance in the colour of grape juices and wines. As pigments they are almost exclusively responsible for the red, blue and purple colours in berries. As expected, the anthocyanins were high in the GSK and low in the WG and GSD, due to the fact that they are mainly stored in the vacuoles of the exocarp (peel) cells of grapes. The results indicate that the TAC is localised predominantly in the skins of grapes. These findings are consistent with data published previously (Yilmaz \& Toledo, 2006; Arnous \& Meyer, 2008), despite differences in extraction method.
In the phenolic pool of red grape skins and seeds, there are some secondary compounds that are important for their antioxidant activity: catechin and epicatechin (flavan-3-ols), quercetin and its glycoside rutin (flavonols), and trans-resveratrol (stilbene). These compounds have been proven to be potent antioxidants and to have important biological, pharmacological and medicinal properties (Auger et al., 2004; Kammerer et al., 2004; Maier et al., 2009). Trans-resveratrol was found at low levels in all the samples, with an average of $3.16 \mathrm{mg} / 100 \mathrm{~g} \mathrm{db}$. Compared with the trans-resveratrol level described by Kammerer et al. (2004), the content in the GSD $(1.42 \mathrm{mg} / 100 \mathrm{~g} \mathrm{db})$ was lower than our 
finding $(2.85 \mathrm{mg} / 100 \mathrm{~g} \mathrm{db})$. The exception was the GSK $(8.64$ $\mathrm{mg} / 100 \mathrm{~g} \mathrm{db}$ ), which showed a higher level than our finding (3.60 $\mathrm{mg} / 100 \mathrm{~g} \mathrm{db}$ ). Among the tissues analysed, the GSD showed the highest content of $(+)$-catechin $(231.92 \mathrm{mg} / 100 \mathrm{~g} \mathrm{db})$. Compared with some other GSD, as described by Maier et al. (2009), the content of $(+)$-catechin in seeds from seven grape (Vitis vinifera L.) cultivars ('Cabernet Mitos', 'Lemberger', 'Spatburgunder', 'Samtrot', 'Muller-Thurgau', 'Kerner' and 'Schwarzriesling') grown in southern Germany ranged from $88.0 \mathrm{mg} / 100 \mathrm{~g} \mathrm{db}$ to $464.0 \mathrm{mg} / 100 \mathrm{~g} \mathrm{db}$, with an average value of $201.43 \mathrm{mg} / 100 \mathrm{~g}$ $\mathrm{db}$, which is lower than that of the GSD of the cultivar Shiraz ( $231.92 \mathrm{mg} / 100 \mathrm{~g} \mathrm{db}$ ) cultivated in Thailand. On the other hand, Kammerer et al. (2004) reported that the GSD and GSK from a white grape cultivar ( $V$. vinifera $\mathrm{L}$. cv. Weisser Riesling) had a (+)-catechin content of $79.02 \mathrm{mg} / 100 \mathrm{~g} \mathrm{db}$ and $22.67 \mathrm{mg} / 100 \mathrm{~g}$ $\mathrm{db}$ respectively, which was lower than our finding. Auger et al. (2004) reported that the (+)-catechin in WG from a red grape (Vitis vinifera L.) variety cultivated in the Mediterranean ranged from $9.40 \mathrm{mg} / 100 \mathrm{~g} \mathrm{db}$ to $116.50 \mathrm{mg} / 100 \mathrm{~g} \mathrm{db}$, with an average level of $37.70 \mathrm{mg} / 100 \mathrm{~g} \mathrm{db}$, which was lower than our finding $(52.30 \mathrm{mg} / 100 \mathrm{~g} \mathrm{db})$. As can be observed, the amounts of (-)-epicatechin present in the GSD (174.10 mg/100 g db) were higher than those in the GSK $(51.20 \mathrm{mg} / 100 \mathrm{~g} \mathrm{db})$ and WG $(27.92$ $\mathrm{mg} / 100 \mathrm{~g} \mathrm{db}$ ). Similar results have been reported in white grape cultivars ( $V$. vinifera L. cv. Weisser Riesling) by Kammerer et al. (2004). The high levels of procyanidin B1 $(240.13 \mathrm{mg} / 100 \mathrm{~g}$ $\mathrm{db})$, procyanidin B2 (484.08 $\mathrm{mg} / 100 \mathrm{~g} \mathrm{db})$ and some individual procyanidins $(724.21 \mathrm{mg} / 100 \mathrm{~g} \mathrm{db})$ were present mainly in the grape seeds. Bozan et al. (2008) reported that the procyanidins in the GSD from red grape (Vitis vinifera L.) varieties cultivated in Turkey ranged from $56.00 \mathrm{mg} / 100 \mathrm{~g}$ db to $194.00 \mathrm{mg} / 100 \mathrm{~g} \mathrm{db}$ (procyanidin B1), with an average level of $98.00 \mathrm{mg} / 100 \mathrm{~g} \mathrm{db}$, and $52.00 \mathrm{mg} / 100 \mathrm{~g}$ db to $160.00 \mathrm{mg} / 100 \mathrm{~g} \mathrm{db}$ (procyanidin B2), with an average level of $90.00 \mathrm{mg} / 100 \mathrm{~g} \mathrm{db}$. In addition, Kammerer et al. (2004) reported that the amount of procyanidin B2 in the GSD from red grapes (Vitis vinifera L. cv. Weisser Riesling) was $50.62 \mathrm{mg} / 100 \mathrm{~g} \mathrm{db}$, which is lower than the levels found in this study. These findings can be attributed to the large variability in the (+)-catechin, (-)-epicatechin and procyanidin composition of samples from north-eastern Thailand and other regions, and depend on the variety of the grapevine, as well as viticultural and environmental factors (Broussaud et al., 1999).

In the group of phenolic acids, the highest amounts were exhibited in the case of gallic acid, followed by ferulic acid, with trace amounts of caffeic acid and ellagic acid. The highest amounts of gallic acid were noted in the GSD, with an average level of $27.80 \mathrm{mg} / 100 \mathrm{~g} \mathrm{db}$. Compared to our results, Kammerer et al. (2004) reported a lower concentration of gallic acid content in the skins and seeds of white grapes (Vitis vinifera L. cv. Merzling), ranging from 1.50 to $10.65 \mathrm{mg} / 100 \mathrm{~g} \mathrm{db}$. On the other hand, Maier et al. (2009) reported that the gallic acid content in GSD ranged from $18.87 \mathrm{mg} / 100 \mathrm{~g} \mathrm{db}$ ('Muller-Thurgau') to $33.21 \mathrm{mg} / 100 \mathrm{~g} \mathrm{db}$ ('Lemberger'), which is similar to our findings.

A number of methods for measuring antiradical activity have been reported in recent years. Of these, the FRAP (ferric reducing antioxidant power) (Benzie \& Strain, 1996) and the TRAP (total radical-trapping antioxidant parameter) (Wayner et al., 1985) have gained popularity because they are simple and quick.
However, compared to other antiradical methods, these methods have some kinetic or mechanistic flaws (Ou et al., 2001). From a methodological point of view, the DPPH (2,2-diphenyl-1picrylhydrazyl) assays (Cai \& Corke, 2003) are recommended as easy and accurate methods for measuring the antiradical activity of fruit and vegetable juice or extracts.

A large number of studies have been conducted on GSD and have demonstrated excellent free radical scavenging, cardioprotective properties and antiplatelet activity (Vitseva et al., 2005). In most cases, the activities of GSD are related to its anti-oxidative properties and are attributed mainly to the phenolic compounds. In general, the major bioactive compounds in grape seed extract are (+)-catechin, (-)-epicatechin and procyanidins (Yilmaz \& Toledo, 2006). The data obtained reveal that the GSD phenolics are free-radical scavengers and primary antioxidants that react with free radicals. However, these results indicate that the phenolics present in the GSD have free radical-scavenging activities that are more significant $(p<0.05)$ than those present in the GSK, despite the fact that the red grape skin contains phenolic substances that embrace many classes of compounds, ranging from phenolic acids, coloured anthocyanins and simple flavonoids to complex flavonoids (Broussaud et al., 1999; Auger et al., 2004; Kammerer et al., 2004; Rodriguez et al., 2006; Maier et al., 2009). On the other hand, Escribano-Bailon et al. (1992) have reported 17 chemical constituents in Vitis vinifera grape seeds that are all monomers or polymers of flavan-3-ols. The major compounds are $(+)$-catechin $(11 \%),(-)$-epicatechin $(10 \%),(-)$-epicatechin-3-O-gallate $(9 \%)$, epicatechin 3-O-gallate- $(4 \beta \rightarrow 8)$-catechin (dimer B1-3-O-gallate) $(7 \%)$ and epicatechin- $(4 \beta \rightarrow 8)$-epicatechin (dimer B2) $(6 \%)$. The activity of the extracts is attributed to their hydrogen-donating ability (Shimada et al., 1992). The higher activity of the GSD, GSK and WG can be attributed to a more elevated concentration of TPC and antioxidants. Antioxidant compounds are believed to intercept the free radical chain of oxidation and to give hydrogen from the phenolic hydroxyl groups, thereby forming a stable end product that does not initiate or propagate further oxidation of the lipid (Shimada et al., 1992). The data obtained reveal that the extracts are free-radical inhibitors and primary antioxidants that react with free radicals.

The $\mathrm{EC}_{50}$ value, defined as the concentration of extract required for $50 \%$ scavenging of DPPH or hydroxyl radicals under the experimental conditions employed, is a parameter widely used to measure free radical-scavenging activity; a smaller $\mathrm{EC}_{50}$ value corresponds to a higher antioxidant activity. It was observed that all the tissues investigated had high hydroxyl radical-scavenging activity. The lowest $\mathrm{EC}_{50}$ values found were for the GSD $(0.47$ $\mu \mathrm{g} / \mathrm{mL}$ ), which was also the richest in phenolics. These findings were higher than those described by Bozan et al. (2008), who found that the DPPH $\left(\mathrm{EC}_{50}\right)$ free radical-scavenging activities of grape seeds from a variety of cultivars ('Merlot', 'Cabernet', 'Cinsault', 'Papaz Karasi', 'Ada Karasi', 'Hamburg Muscat', 'Alphonso Lavallee', 'Okuzgozu', 'Bogazkere', 'Senso' and 'Kalecik Karasi') cultivated in Turkey ranged from $2.71 \mu \mathrm{g} / \mathrm{mL}$ to $4.62 \mu \mathrm{g} / \mathrm{mL}$, with an average value of $3.31 \mu \mathrm{g} / \mathrm{mL}$. It is interesting to consider the correlation between phenolic composition and the antioxidant activities of GSD and GSK extracts, as phenolic compounds contribute directly to antioxidant activity. Both extracts had high TPC and high DPPH-scavenging activity. This 
heightened activity might be ascribed to certain constituents that are particularly responsible for the strong antioxidant effect (Guendez et al., 2005). The synergic effect of the antioxidants in the extracts should also be considered (Sun \& Ho, 2005). Antiradical capacity $\left(\mathrm{A}_{\mathrm{AR}}\right)$ is defined as the amount of antioxidant necessary to decrease the initial $\mathrm{DPPH} \cdot$ concentration by $50 \%$ and is expressed as 1/EC50. A high value of $\mathrm{A}_{\mathrm{AR}}$ refers to high antioxidant activity. The highest value of $A_{A R}$ was found in the GSD, which was also the richest in phenolics, whereas GSK and WG exhibited the weakest activity. Llobera and Canellas (2007) state that grape pomace presents a high antiradical activity $\left(\mathrm{A}_{\mathrm{AR}}=\right.$ 0.71 ); this coincides with our findings in the GSK.

Microbial activity is a primary cause of the deterioration of many foods and is often responsible for the loss of quality and safety. Concern over pathogenic and spoilage microorganisms in foods is increasing due to the increase in outbreaks of foodborne disease. Disc diffusion methods are used extensively to investigate the antimicrobial activity of grape extracts. These assays are based on the use of discs as reservoirs containing the solution of substances to be examined. In the case of solutions with a low activity, however, a large concentration or volume is needed. The limited capacity of discs means that holes or cylinders are preferred (Mackeen et al., 1997). GSD has been shown to possess antimicrobial properties, particularly inhibition of Gram-positive Bacillus cereus ATCC 11778, Bacillus subtilis ATCC 6633, Staphylococcus aureus ATCC 13150, Streptococcus faecalis TISTR 459 and Streptococcus cremoris TISTR 058. It contains large quantities of phenolic compounds, such as gallic acid, catechin, epicatechin and epicatechin-3-O-gallate, and dimeric, trimeric and tetrameric procyanidins (Broussaud et al., 1999; Auger et al., 2004; Kammerer et al., 2004; Rodriguez et al., 2006; Yilmaz \& Toledo, 2006; Maier et al., 2009). Shoko et al. (1999) have reported antimicrobial activity of methanol extract from grape seeds. The active compound for the inhibition of $E$. coli and Salmonella enteritidis was identified as gallic acid.

It has been reported that Gram-negative bacteria have low susceptibility to plant extracts when compared to Grampositive bacteria. The resistance of Gram-negative bacteria to antibacterial substances is related to lipopolysaccharides in their outer membrane. Generally, the extent of the inhibitory effects of the extracts could be attributed to their phenolic composition. The GSD and GSK had high total phenolic contents compared to those of the WG, which did not inhibit any of the Gram-negative bacteria and yeast tested. Similarly, Shoko et al. (1999) confirmed that phenolics were the most important compounds active against bacteria. They also identified gallic acid as the most active compound for the inhibition of bacteria. Our results suggest that GSD and GSK may be exploitable as antibacterial agents to prevent the deterioration of stored foods by bacteria.

\section{CONCLUSIONS}

The phenolic composition of grapes depends on multiple factors, including climate, degree of ripeness, berry size and grapevine variety. However, it may be concluded that the phenolic compounds, i.e. (+)-catechin, (-)-epicatechin, procyanidins and gallic acid reside mainly in the grape seeds of the cultivar Shiraz grown in Thailand's warm climate, whereas rutin, myricetin, naringenin and kaempferol are presented in the grape skins. The results obtained in this study show that large differences are found between the tissues analysed in relation to their phenolic content. GSD and GSK were richest in both total and individual phenolic content among the tissues studied, showed the highest antioxidant activity and could be further evaluated as dietary supplements. The activity of the GSD and GSK against both Gram-positive and Gram-negative bacteria may be an indication of the presence of a broad spectrum of antibiotic compounds that are distributed mainly in the seed and skin. These data suggest that these GSD and GSK may have low concentrations of extract that act as natural additives to prevent the deterioration of stored foods by bacteria. In addition, these extracts may serve as natural anti-oxidative additives that do not produce toxic effects or impart an unpleasant taste/colour to foods. After these screening experiments, further work will be performed to describe the antioxidative and antimicrobial activities in more detail.

\section{LITERATURE CITED}

Arnous, A. \& Meyer, A.S., 2008. Comparison of methods for compositional characterization of grape (Vitis vinifera L.) and apple (Malus domestica) skins. Food Bioprod. Process. 86, 79-86.

Auger, C., Al-Awwadi, N., Bornet, A., Jean-Max, R., Gasc, F., Cros, G. \& PierreLouis, T., 2004. Catechins and procyanidins in Mediterranean diets. Food Res. Int. 37, 233-245.

Benzie, I.F.F. \& Strain, J.J., 1996. The ferric reducing ability of plasma (FRAP) as a measure of "Antioxidant power": the FRAP assay. Anal. Biochem. 239, 70-76.

Bozan, B., Tosun, G. \& Ozcan, D., 2008. Study of polyphenol content in the seeds of red grape (Vitis vinifera L.) varieties cultivated in Turkey and their antiradical activity. Food Chem. 109, 426-430.

Broussaud, F., Cheynier, V., Asselin, C. \& Moutounet, M., 1999. Flavonoid compositional differences of grapes among site test plantings of Cabernet franc. Am. J. Enol. Vitic. 50, 277-284.

Butkhup, L. \& Samappito, S., 2008. An analysis on flavonoids contents in Mao Luang fruits of fifteen cultivars (Antidesma bunius), grown in northeast Thailand. Pak. J. Biol. Sci. 11, 96-1002.

Caillet, S., Salmieri, S. \& Lacroix, M., 2006. Evaluation of free radical-scavenging properties of commercial grape phenol extracts by a fast colorimetric method. Food Chem. 95, 1-8.

Cai, Y., Sun, M. \& Corke, H., 2003. Antioxidant activity of betalains from plants of the Amaranthaceae. J. Agric. Food Chem. 51, 2288-2294.

Cosme, F., Ricardo-Da Silva, J.M. \& Laureano, O., 2009. Tannin profiles of Vitis vinifera L. cv. red grapes growing in Lisbon and from their monovarietal wines. Food Chem. 112, 197-204

Dewanto, V., Wu, X., Adom, K.K. \& Liu, R.H., 2002. Thermal processing enhances the nutritional value of tomatoes by increasing total antioxidant activity. J. Agric. Food Chem. 50, 3010-3014.

Downeya, M.O. \& Rochfort, S., 2008. Simultaneous separation by reversed-phase high-performance liquid chromatography and mass spectral identification of anthocyanins and flavonols in Shiraz grape skin. J. Chromatogr. A 1201, 43-47.

Escribano-Bailon, T., Gutierrez-Fernandez, Y., Rivas-Gonzalo, J.C. \& SantosBuelga, C., 1992. Characterization of procyanidins of Vitis vinifera variety tintal del pais grape seeds. J. Agric. Food Chem. 40, 1794-1799.

Guendez, R., Kallithraka, S., Makris, D.P. \& Kefalas, P., 2005. Determination of low molecular weight phenolic constituents in grape (Vitis vinifera sp.) seed extracts: correlation with antiradical activity. Food Chem. 89, 1-9.

Jayaprakasha, G.K., Selvi, T. \& Sakariah, K.K., 2003. Antibacterial and antioxidant activities of grape (Vitis vinifera) seed extracts. Food Res. Int. 36, 117-122.

Kahkonen, M.P., Hopia, A.I., Vuorela, H.J., Rauha, J.P., Pihlaja, K. \& Kujala, T.S., 1999. Antioxidant activity of plant extract containing phenolic compounds. J. Agric. Food Chem. 47, 3954-3962.

Kammerer, D., Claus, A., Carle, R. \& Schieber, A., 2004. Phenolic screening of pomace from red and white grape varieties (Vitis vinifera L.) by HPLC-DAD-MS/ MS. J. Agric. Food Chem. 52, 4360-4367. 
Kanner, J., Frankel, E., Granit, R., German, B. \& Kinsella, E., 1994. Natural antioxidants in grapes and wines. J. Agric. Food Chem. 42, 64-69.

Kerem, Z., Bravdo, B., Shoseyov, O. \& Tugendhaft, Y., 2004. Rapid liquid chromatography-ultraviolet determination of organic acids and phenolic compounds in red wine and must. J. Chromatogr. 1052, 211-215.

Lee, J., Durst, R.W. \& Wrolstad, R.E., 2005. Determination of total monomeric anthocyanin pigment content of fruit juices, beverages, natural colorants, and wines by the $\mathrm{pH}$ differential method: collaborative study. J. AOAC Int. 88, 12691278 .

Llobera, A. \& Canellas, J., 2007. Dietary fibre content and antioxidant activity of Manto Negro red grape (Vitis vinifera): pomace and stem. Food Chem. 101, 659-666.

Macheix, J.J., Sapis, J.C. \& Fleuriet, A., 1991. Phenolic compounds and polyphenoloxidase in relation to browning in grapes and wines. Crit. Rev. Food Sci. Nutr. 30, 441-486.

Mackeen, M.M., Ali, A.M., El-Sharkawy, S.H., Manap, M.Y., Salleh, K.M., Lajis, N.H. \& Kawazu, K., 1997. Antimicrobial and cytotoxic properties of some Malaysian traditional vegetables. Int. J. Pharmacogn. 35, 237-243.

Maier, T., Schieber, A., Kammerer, D.R. \& Carle, R., 2009. Residues of grape (Vitis vinifera L.) seed oil production as a valuable source of phenolic antioxidants. Food Chem. 112, 551-559.

Makris, D.P., Boskou, G. \& Andrikopoulos, N.K., 2007. Polyphenolic content and in vitro antioxidant characteristics of wine industry and other agri-food solid waste extracts. J. Food Comp. Anal. 20, 125-132.

Ou, B., Hampsch-Woodill, M. \& Prior, R.L., 2001. Development and validation of an improved oxygen radical absorbance capacity assay using fluorescein as the fluorescent probe. J. Agric. Food Chem. 49, 4619-4626.

Pisarra, J., Mateus, N., Rivas-Gonzalo, J., Santos-Buelga, C. \& De Freitas, V., 2003. Reaction between malvidin 3-glucoside and (+)-catechin in model solutions containing different aldehydes. J. Food Sci. 68, 476-481.

Poudel, P.R., Tamura, H., Kataoka, I. \& Mochioka, R., 2008. Phenolic compounds and antioxidant activities of skins and seeds of five wild grapes and two hybrids native to Japan. J. Food Comp. Anal. 21, 622-625.

Rodriguez, M.R., Romero Peces, R., Chacon Vozmediano, J.L., Martinez Gascuena, J. \& Garcia Romero, E., 2006. Phenolic compounds in skins and seeds of ten grape Vitis vinifera varieties grown in a warm climate. J. Food Comp. Anal. 19, 687-693.

Santos Buelga, C. \& Scalbert, A., 2000. Proanthocyanidins and tannin like compounds - nature, occurrence, dietary intake and effects on nutrition and health. J. Sci. Food Agric. 80, 1094-1117.

Shimada, K.K., Fujikawa, K.Y. \& Nakamura, T. 1992. Antioxidative properties of xanthan on autooxidation of soybean oil in cyclodextrin. J. Agric. Food Chem. 40, 945-948.

Shoko, T., Soichi, T., Megumi, M.M., Eri, F., Jun, K. \& Michiko, W., 1999. Isolation and identification of an antibacterial compound from grape and its application to foods. Nippon Nogeikagaku Kaishi 73, 125-128.

Singletary, K.W., Kwan-Jae, J. \& Giusti, M., 2007. Anthocyanin-rich grape extract blocks breast cell DNA damage. J. Med. Food 10, 244-251.

Sun, T. \& Ho, C.-T., 2005. Antioxidant activities of buckwheat extracts. Food Chem. 90, 743-749.

Teissedre, P.L., Frankel, E.N., Waterhouse, A.L., Peleg, H. \& German, J.B., 1996. Inhibition of in vitro human LDL oxidation by phenolic antioxidants from grapes and wines. J. Sci. Food Agric. 70, 55-61.

Vattem, D.A., Lin, Y.T. \& Shetty, L.K., 2004. Antimicrobial activity against select food-borne pathogens by phenolic antioxidants enriched in cranberry pomace by solid-state bioprocessing using the food grade fungus Rhizopus oligosporus. Proc. Biochem. 39, 1939-1946.

Vitseva, O., Varghese, S., Chakrabarti, S., Folts, J.D. \& Freedman, J.E., 2005. Grape seed and skin extracts inhibit platelet function and release of reactive oxygen intermediates. J. Cardiovasc. Pharmacol. 46, 445-451.

Wayner, D.D.M., Burton, G.W., Ingold, K.U. \& Locke, S., 1985. Quantitative measurement of the total, peroxyl radical-trapping antioxidant capability of human blood plasma by controlled peroxidation. The important contribution made by plasma proteins. FEBS Letts 187, 33-37.

Woraratphoka, J., Intarapichet, K. \& Indrapichate, K., 2007. Phenolic compounds and antioxidative properties of selected wines from the northeast of Thailand. Food Chem. 104, 1485-1490

Yilmaz, Y. \& Toledo, R.T., 2006. Oxygen radical absorbance capacities of grape/ wine industry byproducts and effect of solvent type on extraction of grape seed polyphenols. J. Food Comp. Anal. 19, 41-48. 